\title{
Increasing surface ozone concentrations in the background atmosphere of Southern China, 1994-2007
}

\author{
T. Wang ${ }^{1}$, X. L. Wei ${ }^{1}$, A. J. Ding ${ }^{1}$, C. N. Poon ${ }^{1}$, K. S. Lam ${ }^{1}$, Y. S. Li ${ }^{1}$, L. Y. Chan ${ }^{1}$, and M. Anson ${ }^{2}$ \\ ${ }^{1}$ Department of Civil and Structural Engineering, The Hong Kong Polytechnic University, Hong Kong, China \\ ${ }^{2}$ Faculty of Construction and Land Use, The Hong Kong Polytechnic University, Hong Kong, China
}

Received: 13 April 2009 - Published in Atmos. Chem. Phys. Discuss.: 28 April 2009

Revised: 10 August 2009 - Accepted: 13 August 2009 - Published: 31 August 2009

\begin{abstract}
Tropospheric ozone is of great importance with regard to air quality, atmospheric chemistry, and climate change. In this paper we report the first continuous record of surface ozone in the background atmosphere of South China. The data were obtained from 1994 to 2007 at a coastal site in Hong Kong, which is strongly influenced by the outflow of Asian continental air during the winter and the inflow of maritime air from the subtropics in the summer. Three methods are used to derive the rate of change in ozone. A linear fit to the 14-year record shows that the ozone concentration increased by $0.58 \mathrm{ppbv} / \mathrm{yr}$, whereas comparing means in years 1994-2000 and 2001-2007 gives an increase of $0.87 \mathrm{ppbv} / \mathrm{yr}$ for a 7 -year period. The ozone changes in air masses from various source regions are also examined. Using local wind and carbon monoxide (CO) data to filter out local influence, we find that ozone increased by $0.94 \mathrm{ppbv} / \mathrm{yr}$ from 1994 2000 to 2001-2007 in air masses from Eastern China, with similar changes in the other two continent-influenced airmass groups, but no statistically significant change in the marine air. An examination of the nitrogen dioxide $\left(\mathrm{NO}_{2}\right)$ column obtained from GOME and SCIAMACHY reveals an increase in atmospheric $\mathrm{NO}_{2}$ in China's three fastest developing coastal regions, whereas $\mathrm{NO}_{2}$ in other parts of Asia decreased during the same period, and no obvious trend over the main shipping routes in the South China Sea was indicated. Thus the observed increase in background ozone in Hong Kong is most likely due to the increased emissions of $\mathrm{NO}_{2}$ (and possibly volatile organic compounds (VOCs) as well) in the upwind coastal regions of mainland China. The $\mathrm{CO}$ data at Hok Tsui showed less definitive changes com-
\end{abstract}

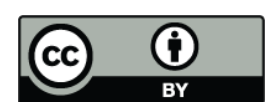

Correspondence to: $\mathrm{T}$. Wang (cetwang@ polyu.edu.hk) pared to the satellite $\mathrm{NO}_{2}$ column. The increase in background ozone likely made a strong contribution $(81 \%)$ to the rate of increase in "total ozone" at an urban site in Hong Kong, suggesting the need to consider distant sources when developing long-term strategies to mitigate local ozone pollution.

\section{Introduction}

Ozone is a key constituent in the troposphere and plays a role in air quality, atmospheric oxidizing capacity, and climate change. At high concentrations, ozone has detrimental effects on human health, crops, and vegetation (NRC, 1991; Chameides et al., 1999). Ozone regulates the oxidizing capacity of the atmosphere via production of the hydroxyl radical which is the principal cleansing reagent in the atmosphere. Ozone is also a greenhouse gas that directly contributes to global warming (IPCC, 2007). Therefore, longterm ozone trends and the underlying cause(s) comprise an area of extensive research worldwide (Vingarzan, 2004; Oltmans et al., 2006; IPCC, 2007, and references cited therein).

The tropospheric ozone burden is determined by downward transport from the stratosphere (Danielsen, 1968), dry deposition to the Earth's surface, and photochemistry in the troposphere involving hydrocarbons, carbon monoxide $(\mathrm{CO})$, and nitrogen oxides $\left(\mathrm{NO}_{\mathrm{x}}\right)$ (Crutzen, 1973). Because of the complex interactions of chemical and meteorological factors, the trends in tropospheric ozone vary both in terms of sign and magnitude and possible causes in different regions of the world (Oltmans et al., 2006; IPCC, 2007). Oltmans et al. (2006) analyzed surface and ozonesonde data collected in $33 \mathrm{rural} / \mathrm{remote}$ areas around the globe and showed that tropospheric ozone increased significantly during the 1970s

Published by Copernicus Publications on behalf of the European Geosciences Union. 
and 1980s in the mid-latitudes of Europe and North America and in Japan, but appeared to have leveled off and in some places declined in the more recent decades. Several recent papers showed increasing surface ozone concentrations at rural sites in the western United States (Jaffe and Ray, 2007; Oltmans, et al., 2008; Parrish et al., 2009), at an Atlantic coastal site in Europe (Parrish et al., 2009), and at surface sites and a mountain-top site in Japan during springtime (Kurokawa et al., 2009; Tanimoto, 2009). Increasing ozone in the free troposphere has also been recently reported for several regions of the Northern Hemisphere based on aircraft and ozonesonde data (Schnadt Proberaj et al., 2009).

The trends in ground-level ozone in the urban and rural areas of industrialized regions are strongly linked to the changes in anthropogenic emissions of ozone precursors (Fiore et al., 1998; USEPA, 2008). In remote areas, changes of ozone precursor emissions in distant source regions, biomass burning, and atmospheric circulation all play an important role in ozone trends, and it can be a considerable challenge to establish the spatial representativeness of the observed trend and to pin down the underlying cause(s), as highlighted by analyses of the ozone trends in rural/remote western United States (Jaffe et al., 2003; Parrish et al., 2004, 2009; Jaffe and Ray, 2007; Oltmans et al., 2008).

China has undergone rapid urbanization and industrial development in the past three decades. A key question is how the anticipated sharp rise in pollutant emissions affects the atmospheric composition of chemically and radiatively important trace gases and aerosols. Although intensive field studies reveal the frequent occurrence of ground level ozone pollution in photochemically active seasons in suburban and rural areas of East China (e.g., Cheung and Wang, 2001; Gao et al., 2005; Shao et al., 2006; Wang et al., 2006a, b), knowledge of the long-term ozone trends in China is very limited because of the lack of long-term continuous data from regionally representative sites. Ding et al. (2008) analyzed aircraft ozone data obtained from the MOZAIC (Measurement of Ozone and Water Vapor by Airbus In-Service Aircraft) program for the 1995-2005 period (with data concentrating in 1997 to 1998 and 2005) and found that summertime ozone in the boundary layer near Beijing had increased by about $2 \%$ per year. Xu et al. (2008) found a positive trend in daytime ozone at a polluted rural site in the Yangtze River Delta, based on data collected during seven measurement campaigns lasting 3-15 months in 1991-2006. In the maritime regions impacted by Asian continental outflow, Chou et al. (2006) reported a positive trend in surface ozone in northern Taiwan for the 1994-2003 period, whereas the data obtained from ozonesondes in 1970-2002 at four Japanese sites indicated no obvious trends during the 1990s in regionally polluted air masses from China (Naja and Akimoto, 2004). Increasing ozone concentrations in Japan were recently reported during springtime at a remote mountainous site in 1998-2006 (Tanimoto, 2009) and at 136 air-quality monitoring stations during 1981-2005 (Kurokawa et al., 2009).
In this report, we present the first long-term and continuous record of surface ozone obtained at a non-urban site from 1994 to 2007 in Southern China. The ozone data were collected at a regional background air monitoring station of The Hong Kong Polytechnic University at Hok Tsui, Hong Kong. Influenced by Asian monsoons, the site receives pollutantladen continental flow in the winter and relatively clean maritime air from the South China Sea in the summer, making it a suitable location to monitor the background ozone of subtropical eastern Asia. First shown are the overall change, seasonal cycles, and changes in four seasons. Then a cluster analysis of back trajectories over the 14 years is conducted to identify the major types of air-mass groups, and the ozone change in each group is examined. Also analyzed are the trends in the satellite-derived nitrogen dioxide $\left(\mathrm{NO}_{2}\right)$ columns in different source regions in Asia and the changes in surface $\mathrm{CO}$ observed at Hok Tsui. Finally, the impact of the background air on the ozone changes in urban Hong Kong is assessed.

\section{Data and methodologies}

\subsection{Study site and instrumentation}

The Hong Kong Polytechnic University's background air monitoring station was established at Hok Tsui to monitor the changes in the composition of background air and to investigate the chemistry and transport of air pollution in subtropical Asia (http://www.cse.polyu.edu.hk/ cetwang/ Researches/Guangdong/HokTsui/index.htm). The station was an integral part of the PEM-West, TRACE-P, and ACEAsia campaigns (Wang et al., 1997; Lam et al., 2001; Wang et al., 2003; Cohen et al., 2004), and has been involved in other intensive studies (see the website for a full list of publications). Figure 1 shows the location of the station in Hong Kong and the Pearl River Delta (PRD) of Guangdong Province. (Also shown in Fig. 1 is a weather station at Waglan (WGL) Island and an urban air quality monitoring station at Central/Western (CW) whose data are used to aid the analysis of the data at Hok Tsui.) The reader is referred to our previous publications for a more detailed description of the Hok Tsui station. Briefly, the site is located at the southeastern tip of Hong Kong Island $\left(22.217^{\circ} \mathrm{N}, 114.25^{\circ} \mathrm{E}, 60 \mathrm{~m}\right.$ above sea level), on a cliff with a $270^{\circ}$ view of the South China Sea. Most of the time, the station is upwind of the urban areas of Hong Kong and the PRD.

Measurement instruments are housed in a temperaturecontrolled container. Ambient air samples are drawn through a perfluoroalkoxy (PFA) Teflon tube (outside diameter, $12.7 \mathrm{~mm}$; inside diameter, $9.6 \mathrm{~mm}$ ), which is connected to a PFA manifold. The length of the sampling tube was $17 \mathrm{~m}$ (14 $\mathrm{m}$ after July 2007). The inlet of the sample line was located $12 \mathrm{~m}$ above the rooftop of the laboratory ( $9 \mathrm{~m}$ after July 2007). A bypass pump draws air at a rate of $15 \mathrm{~L} / \mathrm{min}$. The 

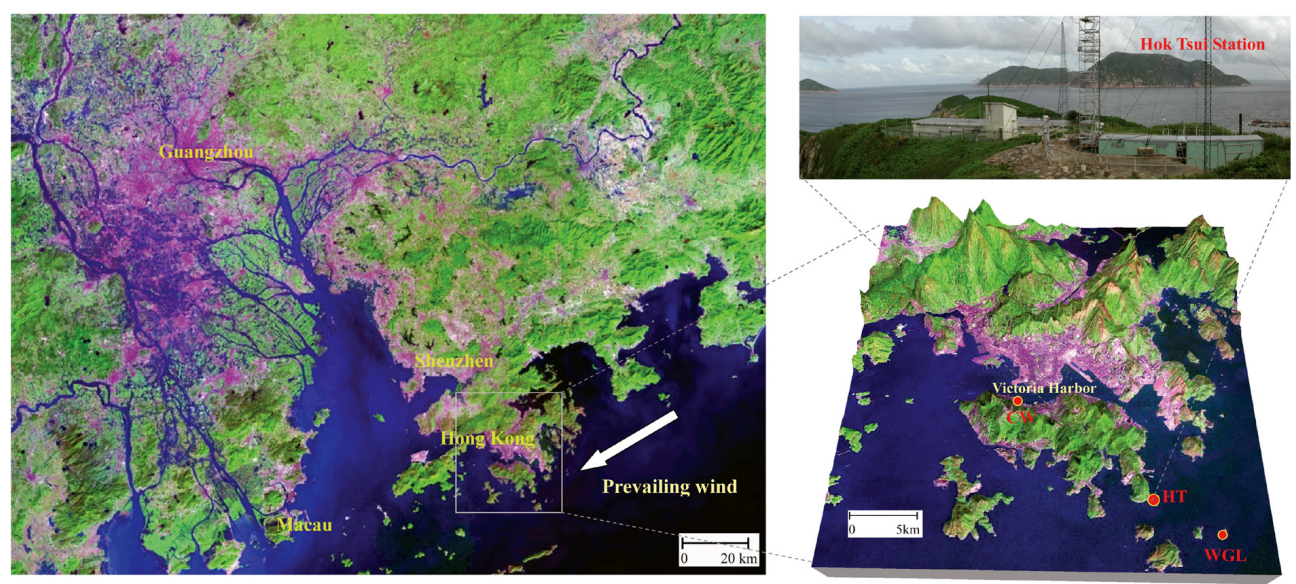

Fig. 1. Map (and photo) showing the location of the Hok Tsui station in Hong Kong and the Pearl River Delta of Guangdong Province. (The purple regions indicate urban areas. Also shown is a weather station at Waglan Island (WGL) and an urban air quality monitoring station at Central/Western (CW) whose data are used to aid the analysis of the data at Hok Tsui.)

residence time of air in the sample line and manifold was $4.2 \mathrm{~s}$ (3.4 s after July 2007). An inline Teflon filter (Fluoroware Inc., Chaska, Minnesota) is placed upstream of each analyzer to prevent particles from entering the analyzer.

Ozone is measured with a commercial UV photometric analyzer (Thermo Environment Instrument Inc. (TEI), Models 49, 49C, and 49i). Zero checks are performed every day by automatically injecting charcoal-scrubbed air (Wang et al., 1997; Lam et al., 2001). The ozone analyzer is calibrated by a UV photometric calibrator (TEI Model 49PS) approximately every six months. The ozone standard has been cross-checked against two National Institute of Standards and Technology (NIST) primary ozone standards maintained by the Hong Kong Environmental Protection Department and National Institute for Environmental Studies of Japan (Tanimoto et al., 2007). Excellent agreement (difference $<1 \%$ ) was obtained.

To facilitate the analysis of ozone trends, the $\mathrm{CO}$ data concurrently measured at the site are also utilized. $\mathrm{CO}$ is measured with a gas filter correlation, non-dispersive infrared absorption instrument (TEI Model 48 before March 2006 and Teledyne API Model 300 thereafter). The reader is referred to Wang et al. (1997), Lam et al. (2001), and Wang et al. (2001) for detailed descriptions of the two instruments. Both analyzers have an internal heated catalyst to convert $\mathrm{CO}$ to $\mathrm{CO}_{2}$ while allowing other gases and water vapor to pass through. Zero checks are conducted every two hours for a period of $15 \mathrm{~min}$. The analyzer is calibrated against a NIST-traceable standard. Both analyzers have been compared with the canister-based sampling method and gas chromatographic analysis technique, with good agreement (within 10\%) achieved.

\subsection{Ozone and $\mathrm{NO}_{\mathrm{x}}$ data at an urban site}

To compare the ozone change at Hok Tsui with that in urban Hong Kong, the ozone and $\mathrm{NO}_{\mathrm{x}}$ data obtained at an urban monitoring station (Central/Western $(\mathrm{CW})$ ) are used in this analysis. This station is in a residential area on the densely populated northern side of Hong Kong Island and is $14.5 \mathrm{~km}$ west of Hok Tsui (see Fig. 1). The station is operated by the Hong Kong Environmental Protection Department. The ozone concentrations at this site have increased since the early 1980s (Chan et al., 2004; http://www.epd-asg. gov.hk/english/report/files/aqr07e.pdf). Ozone is measured with a UV photometric analyzer, and $\mathrm{NO}_{\mathrm{x}}$ with a chemiluminescence analyzer with a heated $\mathrm{MoO}$ catalyst to convert $\mathrm{NO}_{2}$ to $\mathrm{NO}$ (http://www.epd-asg.gov.hk/english/report/files/ aqr07e.pdf). It should be noted that the $\mathrm{NO}_{2}$ determined by this method includes not only $\mathrm{NO}_{2}$ but also some other forms of oxidized reactive nitrogen such as PAN and nitric acid.

\subsection{Satellite data}

Satellite data were used for an examination of the spatial distribution of and changes in $\mathrm{NO}_{2}$, a precursor of photochemically produced ozone. The monthly mean global tropospheric $\mathrm{NO}_{2}$ columns were used, with 0.5 degree resolution, obtained from GOME (Global Ozone Monitoring Experiment) for the 1995-2002 period and SCIAMACHY (Scanning Imaging Absorption Spectrometer for Atmospheric Chartography) from 2003 onwards. These Level 2 products were obtained via TEMIS (Tropospheric Emission Monitoring Internet Service; http://www.temis.nl/index.html), with no additional processing by these authors. 


\subsection{Back trajectories and cluster analysis}

To examine the origin and transport pathways of the largescale air masses arriving at the study site, ten-day back trajectories were calculated for each hour using the Hybrid Single-Particle Lagrangian Integrated Trajectory (HYSPLIT) model Version 4.8 (Draxler and Hess, 1998). The meteorological data used to drive the model were the 6hourly Air Resources Laboratory (ARL) FNL archive data with a resolution of $190 \mathrm{~km}$ for the 1997-2006 period (ftp://www.ready.noaa.gov/pub/archives/fnl). The $2.5^{\circ} \times 2.5^{\circ}$ NCEP/NCAR Reanalysis data (ftp://www.ready.noaa.gov/ pub/archives/reanalysis) were used in lieu of the missing data in the former source in 1994-1997 and in 2007. The endpoint of the trajectories was $300 \mathrm{~m}$ above ground level at the Hok Tsui site, which is in the middle of the marine boundary layer. Cluster analysis (Dorling et al., 1992) was then used to group trajectories into clusters and determine the optimum number of clusters. The results are shown in Sect. 3.2.1.

\subsection{Methods for trend analysis}

For the overall changes in ozone and $\mathrm{CO}$ concentrations over the 14-year period, a linear fit was applied to the monthly averaged data as well as to de-seasonalized monthly data (Jaffe and Ray, 2007). The monthly averages include all time of day. The slope of the least square fit was used to show the rate of change. In addition, the mean values in years 19942000 and 2001-2007 were computed, and average rates of change were obtained by dividing the difference between the means by 7 (i.e., 7 years). To see if a trend exists in each season and in air-mass groups from different source regions, both linear fitting to the seasonally or air-mass averaged data and the method of dividing the data into two periods were used.

To determine if a rate of change is statistically significant, the $p$ value was obtained in the case of the linear fitting method, with $p$ less than or equal to 0.05 being considered statistically significant; a variance test (t-test) was conducted to check if the means in the two periods are significantly different, and a confidence level of at least $95 \%$ is adopted. For the seasonally and air mass averaged data set with a small sample size (14 in our case), the $p$ value in the linear fit may not be the sole criteria for testing the level of statistical significance, because the linear regression assumes that data scatter follows a Gaussian distribution, and this assumption can be violated in cases of small sample size (Motulsky, 1995). Thus if the variance test shows a difference in the mean values is significant at the $95 \%$ confidence level or better, the change is considered to be robust.

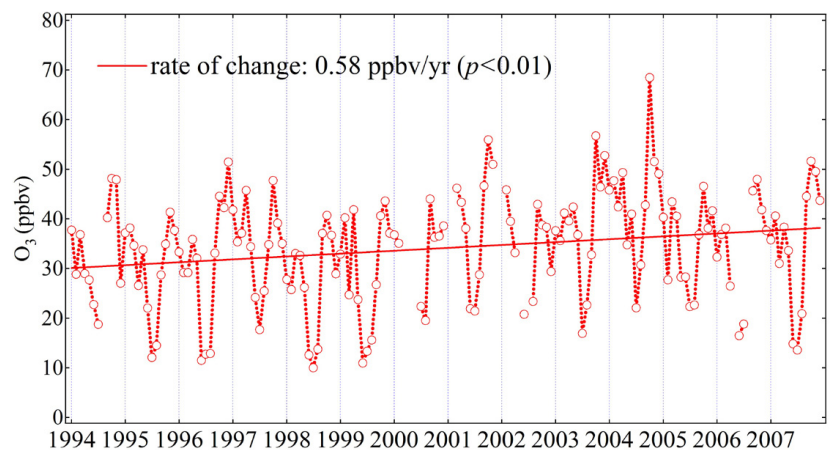

Fig. 2. Monthly mean ozone mixing ratios and the linear fit line at Hok Tsui, Hong Kong, during 1994-2007.

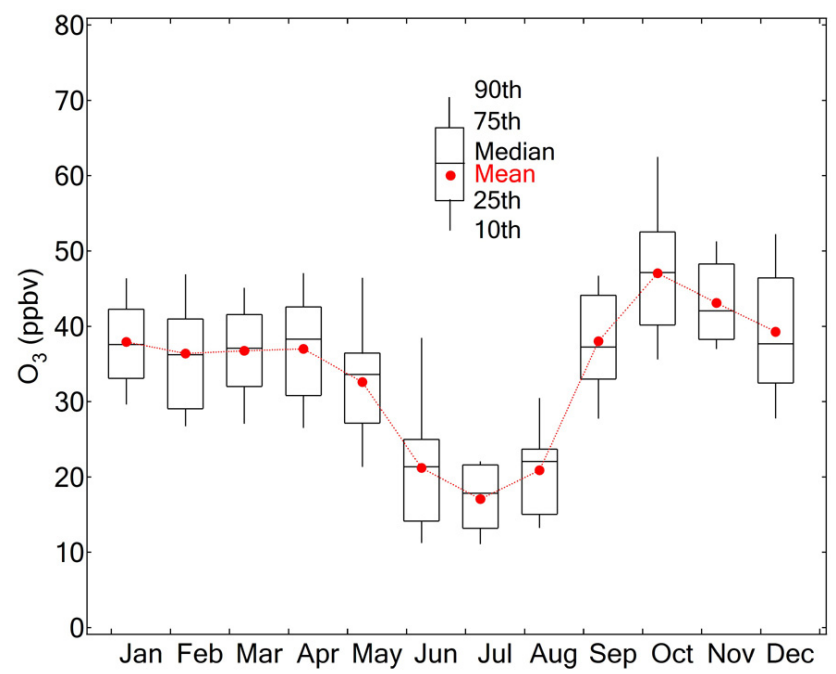

Fig. 3. Whisker plot of the seasonal variation of ozone at Hok Tsui during the 1994-2007 period.

\section{Results and discussion}

\subsection{Overall trend and seasonal pattern of ozone}

Figure 2 shows the monthly averaged ozone over the 1994 2007 period and a linear fit of the monthly data. Overall, there is a statistically significant $(p<0.01)$ increase in ozone during the 14-year period, with a mean rate of change of $0.58 \mathrm{ppbv} / \mathrm{yr}$. A linear fit to the de-seasonalized monthly data (with the use of SPSS software) gives a similar slope $(0.57 \mathrm{ppbv} / \mathrm{yr})$ and $p$ value $(p<0.01)$. The mean ozone in years 2001-2007 is also significantly (at the $99 \%$ confidence level) greater than that in the proceeding period, which gives an average rate of change of $0.87 \mathrm{ppbv} / \mathrm{yr}$. The results from the three methods confirm rising ozone levels at Hok Tsui. Figure 3 shows the composite seasonal pattern of ozone in the 14-year period. A similar seasonal cycle has previously been reported based on the data from shorter periods (13 years) (Lam et al., 2001; Wang et al., 2005), and can 
Table 1. Rate of change in seasonally averaged ozone by two methods.

\begin{tabular}{|c|c|c|c|c|}
\hline \multirow[b]{2}{*}{ Season } & \multicolumn{2}{|c|}{ Linear regression } & \multicolumn{2}{|c|}{$\begin{array}{c}\text { Comparing the difference between } \\
1994-2000 \text { and 2001-2007 }\end{array}$} \\
\hline & rate (ppbv/yr) & $p$ value & rate (ppbv/yr) & confidence level \\
\hline Spring & 0.41 & 0.18 & 0.84 & $99 \%$ \\
\hline Summer & 0.52 & 0.15 & 0.99 & $99 \%$ \\
\hline Autumn & 0.68 & 0.07 & 1.02 & $99 \%$ \\
\hline Winter & 0.50 & 0.12 & 0.73 & $95 \%$ \\
\hline
\end{tabular}

generally be explained by the Asian Monsoon. The dominance of marine air masses, coupled with rainy and unstable weather, leads to low levels of ozone (and other trace gases) in summer. Pollution-laden continental flow from the north, in conjunction with the stable and warm weather in autumn, contributes to the ozone maximum in autumn (winter for primary pollutants such as CO). These 14-years of data give a climatologically average maximum of $47 \mathrm{ppbv}$ in October and minimum of 18 ppbv in July.

Table 1 gives the rate of change in the seasonal ozone averages determined by the linear fit and by comparing the two periods. Winter includes December, January, and February; spring, March, April, and May; summer, June, July and August; and autumn, September, October, and November. (The winter months are in the same year.) The linear fit gives a mean rate of $0.68 \mathrm{ppbv} / \mathrm{yr}$ in autumn, with lower values $(0.50,0.41$ and 0.52$)$ in winter, spring and summer, respectively; the $p$ values are relatively large $(0.07-$ 0.18 ). In comparison, the variance tests indicate significantly greater (at the $95 \%$ confidence level) values in the more recent years. The rate of change was $1.02 \mathrm{ppbv} / \mathrm{yr}$ in autumn, followed by 0.99 ,ppbv/yr in summer, $0.84 \mathrm{ppbv} / \mathrm{yr}$ in spring, and $0.73 \mathrm{ppbv} / \mathrm{yr}$ in winter.

The ozone changes in the four seasons at Hok Tsui are somewhat different from those at another coastal site, WanLi, in northern Taiwan during 1994-2003 (Chou et al., 2006). At the latter site, which is about $800 \mathrm{~km}$ northeast of Hong Kong, the largest rate of increase of ozone occurred in spring $(0.71 \mathrm{ppbv} / \mathrm{yr}, p=0.0044)$, which is determined by the linear fitting method, followed by summer $(0.55 \mathrm{ppbv} / \mathrm{yr}$, $p=0.1467)$, autumn (0.15 ppbv/yr, $p=0.7073)$, and winter ( $0.10 \mathrm{ppbv} / \mathrm{yr}, p=0.7738$ ) (see Table 1 of the reference). In contrast, coastal Hong Kong saw the largest rate of increase in autumn. In comparison with the ozone changes derived from the limited data in source regions in Eastern China, the overall change in Hong Kong was similar to that in the planetary boundary layer over Beijing (Ding et al., 2008). At a polluted rural site, Lin'an, in the Yangtze River Delta, surface ozone showed a larger rate of increase in daytime and a decrease at night, with no obvious overall trend (Xu et al., 2008). The opposite trend in the daytime and nighttime data at Lin'an is attributed to the increase in $\mathrm{NO}_{\mathrm{x}}$ emissions in the region leading to enhanced photochemical production of ozone in the daytime and the titration of ozone at night (Xu et al., 2008). At Hok Tsui, ozone increased both in the daytime and the nighttime (figure not shown), which indicates that the site is not significantly impacted by titration from local sources.

\subsection{Climatology of large-scale transport}

\subsubsection{Transport pattern using cluster analysis}

To discover the origins and transport pathways of air masses in the background atmosphere of Southern China, the results of cluster analysis of the hourly trajectories for 19942007 were examined. Cluster analysis yielded a total of seven air-mass groups. The two marine sub-groups arriving from the southwest and southeast were grouped into one "Marine" group, and three continental air-mass groups into one "East China" group, in part because the concentrations of ozone and $\mathrm{CO}$ were similar in the subgroups. Figure 4 shows the four main groups and the percentage occurrence of each, with shaded areas as the mean $\mathrm{NO}_{2}$ column concentration obtained from GOME and SCIAMACHY for 19962007. The four air-mass groups are: "Marine", "Central China + PRD", "East China", and "Aged continental".

The Marine air mass originated in Southeastern Asia and the surrounding ocean and passed over the South China Sea before arriving at the site. This group, which can be considered background air from the South China Sea, mainly (68\%) occurred in summer (June, July, and August) and accounted for $30 \%$ of all trajectories. The Aged continental air mass originated in continental Asia, spent many days over the East China Sea, and approached Hong Kong from the east. This air mass accounted for $13 \%$ of total trajectories. The East China group originated in Central Asia, and passed over the highly industrialized coastal regions of Eastern China. This group accounted for $45 \%$ of total trajectories, making it the predominant air-mass group. The Central China + PRD air mass passed over central China, the PRD, and Hong Kong. The two latter groups mainly occurred in autumn and winter $(79 \%$ and $68 \%$ of the time, respectively). The altitudes of these groups are also shown. The three continental air groups originated at altitudes higher than those of the marine group. The 14-year trajectory results confirm that large-scale air masses arriving at Hok Tsui are mainly from the northeast and south, and infrequently come from urban Hong Kong itself or the adjacent PRD.

\subsubsection{The ozone changes in different air-mass groups}

Next examined were the ozone changes in the four air-mass groups. As the study site is close to the urban center of Hong Kong and trajectories based on coarse meteorological data may not capture the local to meso-scale dynamic processes that could transport Hong Kong's emissions to the site, we imposed additional constraints when examining the 


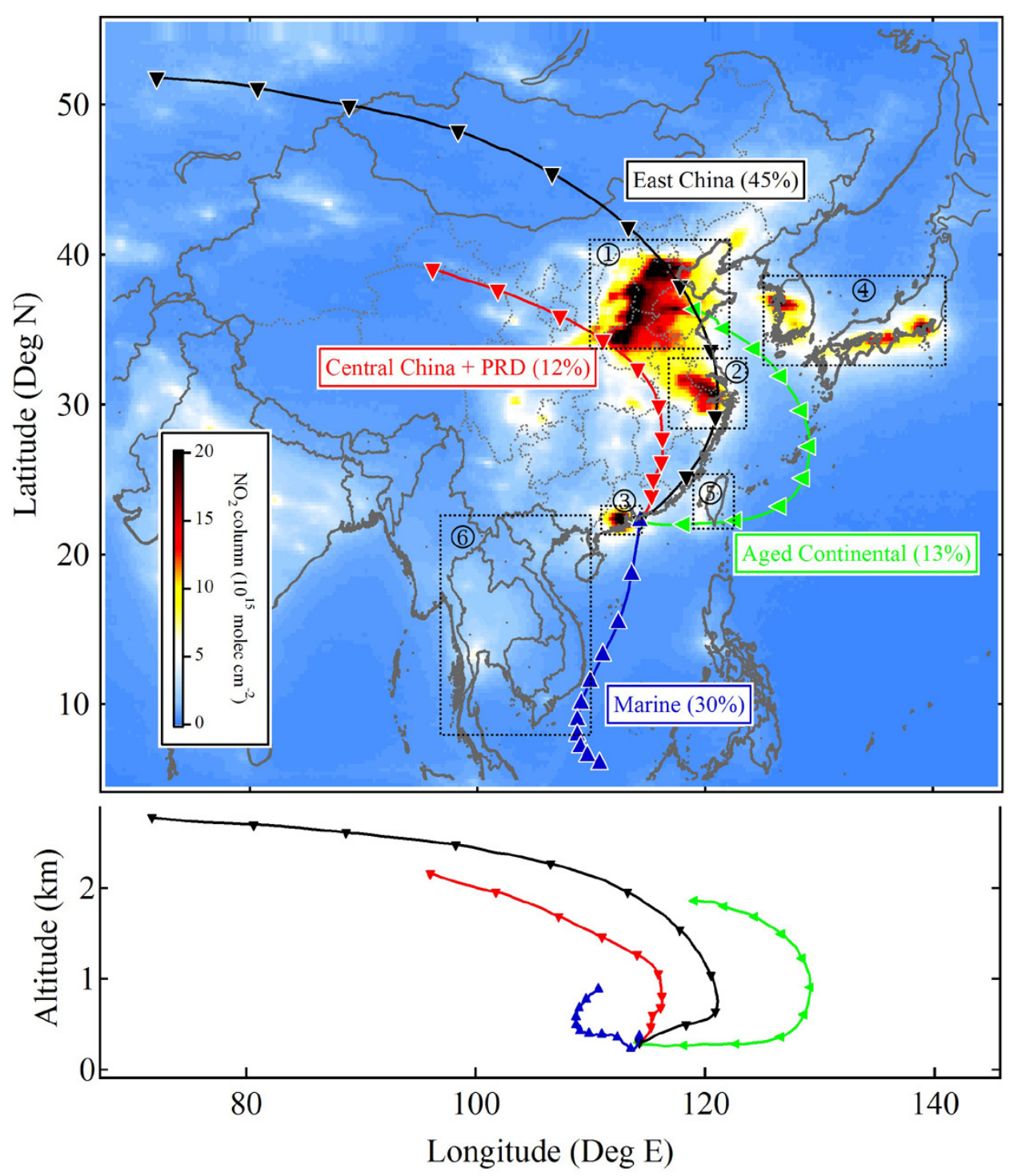

Fig. 4. Four major types of 10-day backward trajectories at Hok Tsui. The percentage of each type during the 1994-2007 period is shown in parentheses. The $\mathrm{NO}_{2}$ column data from GOME and SCIAMACHY (averaged over 1996-2007) are shown in the shaded areas. The boxes in dashed lines are potential sources for ozone at Hok Tsui: (1) NCP: North China Plain, (2) YRD: Yangtze River Delta, (3) PRD: Pearl River Delta, (4) Kr-Jp: Korea and Japan, (5) TW: Taiwan, (6) SA: Southeast Asia.

chemical characteristics of air masses in the Marine, East China, and Aged continental groups. The surface winds observed at Waglan Island (WGL), by the Hong Kong Observatory were used. WGL is situated $8 \mathrm{~km}$ southeast of Hok Tsui (see Fig. 1). The following criteria were adopted: the wind speed at WGL must be greater than $2 \mathrm{~m} / \mathrm{s}$, and the wind direction in the preceding six hours at WGL must be within $20-250^{\circ}$ (i.e., not from urban Hong Kong or the PRD). In addition, for the Marine and Aged continental groups, the concurrently measured $\mathrm{CO}$ must be lower than 400 and $500 \mathrm{ppbv}$, respectively.

Segregating/filtering the ozone data using cluster analysis and the abovementioned criteria led to limited data points distributed unevenly in different seasons and times of the day. As ozone in the lower troposphere has a strong seasonal and diurnal variation, a pooled statistical method (Taylor and Cihon, 2004) was adopted to calculate the mean ozone level in each group. The data in air-mass groups were further divided into 16 sub-groups (four seasons and four time-periods of a day), and the means and standard deviations in the 16 subgroups were pooled to obtain the overall mean and standard deviations for that air-mass cluster. It has been shown that the pooled method gives results with higher levels of statistical significance (Ding et al., 2008). 


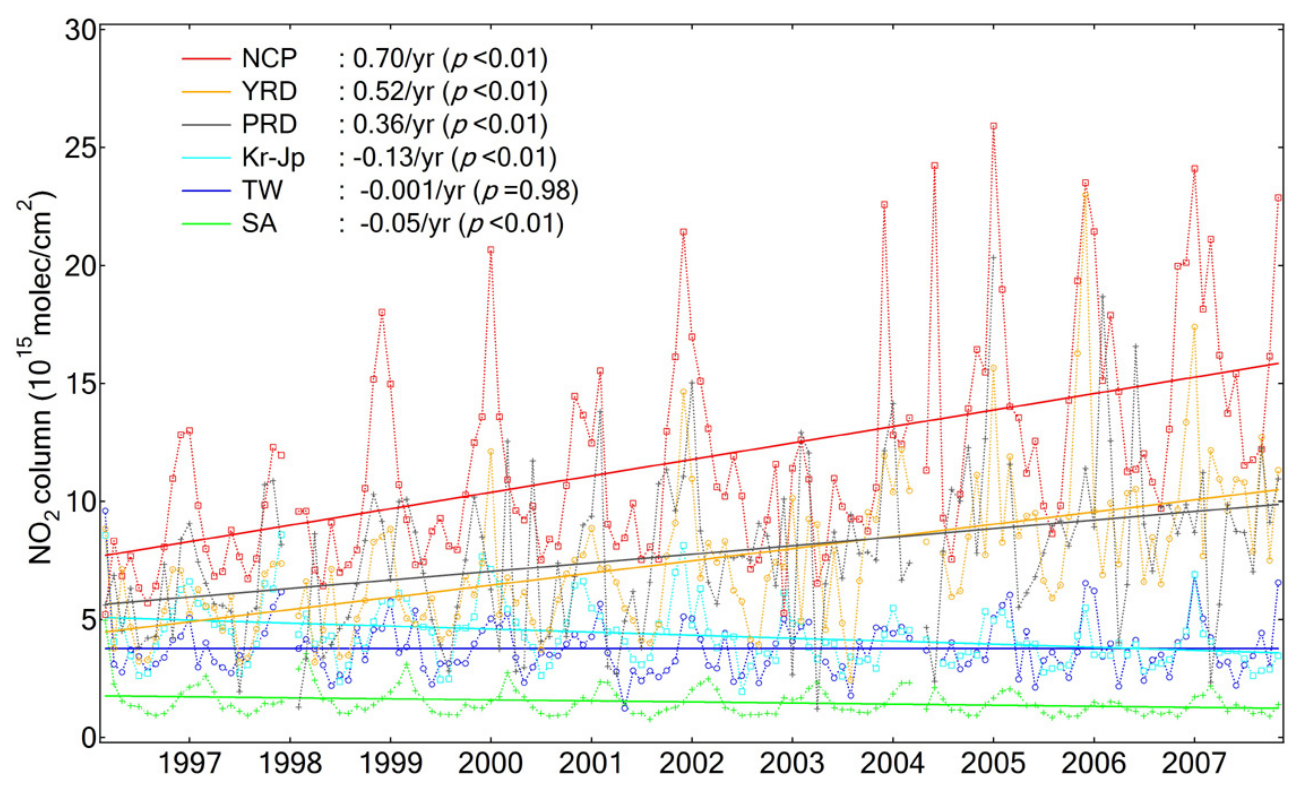

Fig. 5. Monthly mean tropospheric $\mathrm{NO}_{2}$ column concentration retrieved from GOME (March 1996-June 2002) and SCIAMACHY (July 2002-November 2007) for NCP, YRD, PRD, Kr-Jp, TW, and SA.

The means and standard deviations obtained using the pooled method for the ozone and $\mathrm{CO}$ data are shown in Table 2 for the various air-mass groups and with the wind/CO constraints. Due to the very small sample size, winter data are not used for computing the pooled mean for the Marine group, and summer data are not included for the East China and Central China + PRD groups. As expected, the mean $\mathrm{CO}$ concentration was the lowest in the Marine group, with a mean value of $128 \mathrm{ppbv}$ $( \pm 48$ ppbv $)$. The Central China + PRD air mass had the highest $\mathrm{CO}$ concentration ( $488 \mathrm{ppbv} \pm 204 \mathrm{ppbv})$, followed by the East China ( $357 \mathrm{ppbv} \pm 141 \mathrm{ppbv}$ ) and Aged continental $(235 \mathrm{ppbv} \pm 88 \mathrm{ppbv})$ groups. The average ozone was the lowest in the Marine group ( $22 \mathrm{ppbv} \pm 10 \mathrm{ppbv})$, also as expected. The highest ozone concentration was found in the East China group ( $48 \mathrm{ppbv} \pm 14 \mathrm{ppbv}$ ), with lower concentrations in the Central China + PRD ( $42 \pm 20$ ppbv) and Aged continental groups $(38 \pm 16 \mathrm{ppbv})$. The chemical data are consistent with the results of air-mass classification using the back trajectories, in terms of the expected concentrations of the two gases. In the marine air group, the average values of ozone and $\mathrm{CO}$ in summer months (accounting for 68\% of total samples) are $18( \pm 9)$ ppbv and $98( \pm 38)$ ppbv, respectively, which can be considered as their respective background concentrations in the South China Sea region during summer.

Table 3 shows the ozone changes in each air-mass group with the wind and CO filter applied (except for the Central China + PRD group). The linear fits shows a rate of increase of $0.64 \mathrm{ppbv} / \mathrm{yr}$ in the East China group $(p=0.08)$ with the other air-mass groups having a larger $p$ value $(0.21-$
Table 2. Pooled means and standard deviations of ozone and CO in the four air-mass groups.

\begin{tabular}{lcc}
\hline Air mass type & $\mathrm{O}_{3}(\mathrm{ppbv})$ & $\mathrm{CO}(\mathrm{ppbv})$ \\
\hline East China* & $48(14)$ & $357(141)$ \\
Central China + PRD & $42(20)$ & $488(204)$ \\
Aged continental* $^{*}$ & $38(16)$ & $235(88)$ \\
Marine* $^{*}$ & $22(10)$ & $128(48)$ \\
\hline
\end{tabular}

* With the wind/CO filter (see text for detail).

Table 3. Rate of change for yearly pooled average of ozone in the four air-mass groups.

\begin{tabular}{lccc}
\hline & \multicolumn{2}{c}{ Linear regression } & $\begin{array}{c}\text { Comparing the difference } \\
\text { between 1994-2000 and } \\
\text { 2001-2007 (ppbv/yr) }\end{array}$ \\
\hline Air mass type & rate (ppbv/yr) & $p$ value & $0.94^{* *}$ \\
East China* $_{\text {Central China + PRD }}$ & 0.64 & 0.08 & $1.20^{* *}$ \\
Aged Continental $^{*}$ & 0.45 & 0.21 & $0.85^{* *}$ \\
Marine* $^{*}$ & 0.29 & 0.21 & 0.57 \\
\hline
\end{tabular}

* With the wind/CO filter

** Significant at $95 \%$ confidence level

0.27). Comparing the means in the two periods yields an increase (significant at $95 \%$ confidence level) of $0.94 \mathrm{ppbv} / \mathrm{yr}$, $1.20 \mathrm{ppbv} / \mathrm{yr}$, and $0.85 \mathrm{ppbv}$ for the East China, Central China + PRD, and Aged continental air groups, respectively. The Marine air group did not show a significant increase. The results indicate that the increasing ozone observed at Hok 
Tsui is mainly in air masses which have been affected by continental sources.

\subsection{Relationship between the ozone change and anthro- pogenic emissions in source regions}

An important issue is to determine the main cause of the increasing background ozone in coastal South China. Figure 5 shows the change in tropospheric $\mathrm{NO}_{2}$ columns derived from satellite data for various parts of Asia which may have affected the ozone concentrations at Hok Tsui. These regions (see also Fig. 4) include: the North China Plain (NCP, $114^{\circ} \mathrm{E}-120^{\circ} \mathrm{E}, 34^{\circ} \mathrm{N}-41^{\circ} \mathrm{N}$ ), the Yangtze River Delta (YRD, $\left.118^{\circ} \mathrm{E}-123^{\circ} \mathrm{E}, 28^{\circ} \mathrm{N}-33^{\circ} \mathrm{N}\right)$, the Pearl River Delta (PRD, $112^{\circ} \mathrm{E}-115^{\circ} \mathrm{E}, 21^{\circ} \mathrm{N}-24^{\circ} \mathrm{N}$ ), Korea and Japan $\left(\mathrm{Kr}-\mathrm{Jp}, 126^{\circ} \mathrm{E}-140^{\circ} \mathrm{E}, 32^{\circ} \mathrm{N}-39^{\circ} \mathrm{N}\right)$, Taiwan (TW, $119^{\circ} \mathrm{E}-$ $122^{\circ} \mathrm{E}, 22^{\circ} \mathrm{N}-26^{\circ} \mathrm{N}$ ), and Southeast Asia (SA, $98^{\circ} \mathrm{E}-$ $108^{\circ} \mathrm{E}, 10^{\circ} \mathrm{N}-22^{\circ} \mathrm{N}$ ).

Similar to the finding of Richter et al. (2005), the satellite data indicate significant $\mathrm{NO}_{2}$ column increases in China's three most economically developed regions. The North China Plain (which is home to two megacities, Beijing and Tianjin) had the highest mean $\mathrm{NO}_{2}$ column concentration and the largest rate of increase, followed by the Yangtze River Delta (which is home to China's largest city, Shanghai), and the Pearl River Delta (which is the world's major consumer goods manufacturing base). A pronounced seasonal variation in $\mathrm{NO}_{2}$ columns can be seen, with higher $\mathrm{NO}_{2}$ in winter due to the longer lifetime of $\mathrm{NO}_{2}$ and greater $\mathrm{NO}_{\mathrm{x}}$ emissions in northern regions (Richter et al., 2005). In contrast to the increasing trend in $\mathrm{NO}_{2}$ in the three regions of China, an overall flat or decreasing trend in $\mathrm{NO}_{2}$ was observed in Taiwan, Korea and Japan, and Southeast Asia.

Increasing emissions from international shipping (e.g., Eyring et al., 2005) may be an important factor in determining the changes of trace gases and aerosols in coastal zones and over the oceans. Model analysis (Dalsøren et al., 2009) suggests a large contribution ( $>10 \%$ ) of shipping emissions to surface ozone in some coastal areas. To examine whether the increased ozone concentrations at Hok Tsui could be due to increased emissions from international shipping activities, we examined the rate of change in satellite $\mathrm{NO}_{2}$ during 1996-2007 over a large part of Asia (figure note shown). No obvious trend in $\mathrm{NO}_{2}$ over the main shipping routes in the South China Sea and the East China Sea is indicated, despite large increases of $\mathrm{NO}_{2}$ in the major urban/industrial regions of mainland China. It is possible that a small increase in $\mathrm{NO}_{2}$ exists from increased shipping activities but cannot be detected by satellite. It is worth noting that the contribution of ship emissions to total $\mathrm{NO}_{2}$ in China is much smaller compared to other parts of the world (see Fig. 4 in Dalsøren et al., 2009).

The above results suggest that the increasing background ozone in the South China coastal region is associated with the increasing $\mathrm{NO}_{2}$ column concentration in upwind East-

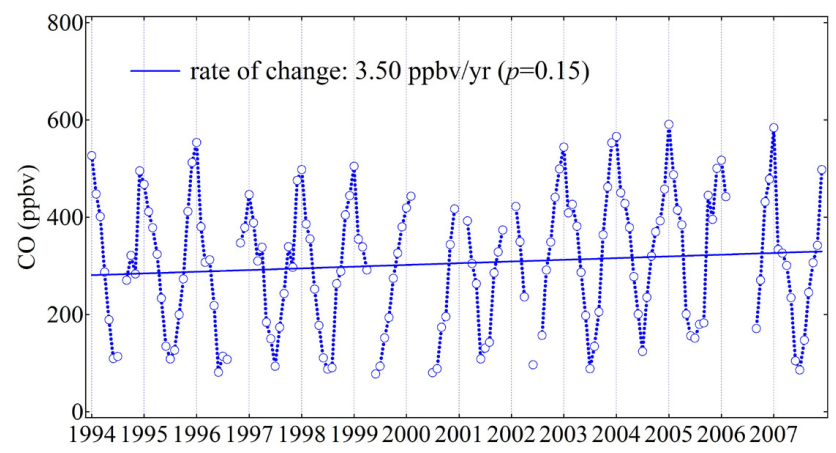

Fig. 6. Monthly mean $\mathrm{CO}$ mixing ratios and the linear fit line at Hok Tsui, Hong Kong, during 1994-2007.

ern China. Although other factors such as climate change may be playing a role in the long-term change in ozone, the pronounced increase in $\mathrm{NO}_{\mathrm{x}}$ (and possibly, volatile organic compound (VOC)) emissions in Eastern China is believed to be the main cause of the increasing ozone levels at Hok Tsui.

Figure 6 shows the monthly mean mixing ratio of $\mathrm{CO}$ at Hok Tsui. CO is produced mainly from burning of fossil fuels and biomass and is a precursor of ozone. The linear fit to the original and de-seasonalized monthly data gives a similar slope of 3.5 versus $3.4 \mathrm{ppbv} / \mathrm{yr}$, but the latter method improved the statistical significance of the result ( $p<0.01$ versus $p=0.15$ ). The mean CO during 20012007 is not significantly different from that in the preceding years as a whole and in each air-mass group. The less definitive change in surface $\mathrm{CO}$ indicates stabilizing emissions of $\mathrm{CO}$ in East Asia, which is in contrast to the rapid rise of $\mathrm{NO}_{2}$ emission. This may be explained by improved efficiencies in China's industries and/or reduced burning of biomass/biofuel. A recent emission inventory (Zhang et al., 2009) suggests a more moderate increase in $C O$ compared to $\mathrm{NO}_{\mathrm{x}}$ during 2001-2006 (18\% versus 55\%). In the Northern Hemisphere, an overall decrease of tropospheric CO has been observed in the past two decades (Novelli et al., 2003, 2007), and in Hong Kong CO emissions have decreased by 55\% during 1994-2007 (http://www.epd.gov.hk/epd/english/ environmentinhk/air/data/emission_inve.html).

\subsection{The impact of background air on ozone in urban Hong Kong}

As for other urban areas, Hong Kong and the adjacent PRD experience serious ozone pollution. Hourly ozone mixing ratios of 150-200 ppbv have been observed in photochemical episodes (e.g., Wang et al., 1998; Zhang et al., 2007, 2008). It is of great interest to see to what extent the change in background ozone has affected the long-term change of ozone in urban Hong Kong. Figure 7 compares the monthly ozone (calculated from all times of day) during 1994-2007 at Hok Tsui, which, as discussed previously, is upwind of 


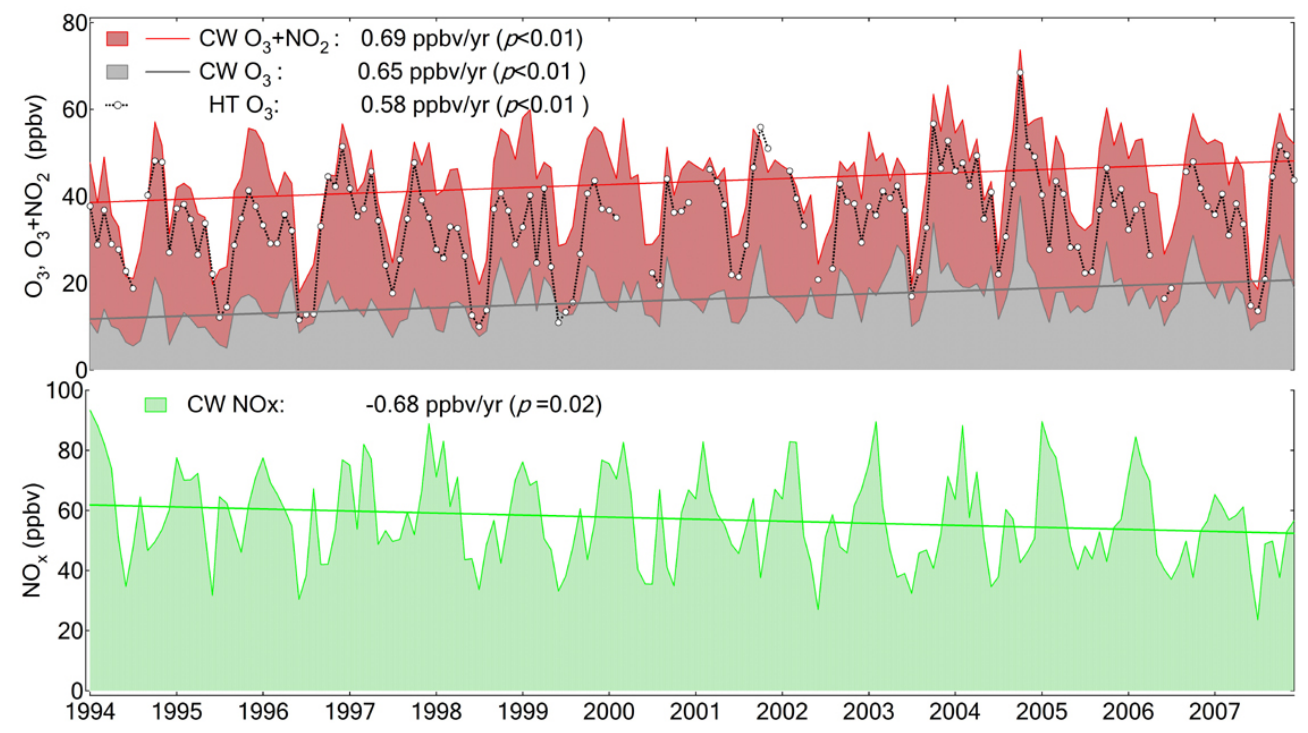

Fig. 7. Monthly mean $\mathrm{O}_{3}$ mixing ratios at Hok Tsui, $\mathrm{O}_{3}$ and $\mathrm{O}_{3}+\mathrm{NO}_{2}$ at an urban site (Central/Western) in Hong Kong, and the linear fit lines (upper panel); $\mathrm{NO}_{\mathrm{X}}$ at Central/Western in Hong Kong (lower panel).

the Hong Kong's urban areas most of the time, with that observed at the urban $\mathrm{CW}$ station. As ozone at $\mathrm{CW}$ is titrated by freshly emitted $\mathrm{NO}$ via $\mathrm{O}_{3}+\mathrm{NO} \rightarrow \mathrm{NO}_{2}+\mathrm{O}_{2}$, we also show $\mathrm{O}_{3}+\mathrm{NO}_{2}$ for the overall oxidant abundance. This quantity includes the amount of ozone that is temporally lost due to the $\mathrm{NO}$ titration and also the $\mathrm{NO}_{2}$ that is directly emitted by vehicles and other local sources. Thus the atmospheric concentration of "total ozone", (Total $\mathrm{O}_{3}$ ), which is defined as the observed $\mathrm{O}_{3}$ in the urban areas plus the $\mathrm{O}_{3}$ that is titrated by NO, can be expressed as:

$$
\left[\text { Total } \mathrm{O}_{3}\right]=\left[\mathrm{O}_{3}+\mathrm{NO}_{2}\right]_{\text {observed }}-\left[\mathrm{NO}_{2}\right]_{\text {directly emitted }}
$$

Figure 7 shows that the ozone level at $\mathrm{CW}$ increased at an average rate of $0.65 \mathrm{ppbv} / \mathrm{yr}$ during the 1994-2007 period, with $\mathrm{O}_{3}+\mathrm{NO}_{2}$ increasing at a slightly higher rate of $0.69 \mathrm{ppbv} / \mathrm{yr}$. Ambient concentrations of $\mathrm{NO}_{\mathrm{x}}$ at $\mathrm{CW}$ decreased during the same period at a rate of $-0.68 \mathrm{ppbv} / \mathrm{yr}$ ( $p=0.02$ ) (see the lower panel in Fig. 7) because of the implementation of several control measures during the period. Measurements in two tunnels in Hong Kong showed a mean vehicular $\mathrm{NO}_{2} / \mathrm{NO}_{\mathrm{x}}$ emission ratio of 0.041 (ppbv/ppbv) (http://www.epd.gov.hk/epd/english/environmentinhk/air/ studyrpts/files/1-pt_final_report_20050225d.pdf). Assuming that this value (obtained in year 2004) can be applied to CW for the entire 14-year period, we can estimate the change in "total ozone" at CW as $0.69-(-0.03)=0.72 \mathrm{ppbv} / \mathrm{yr}$. If we assume $\mathrm{CW}$ is affected by the same air masses as those at Hok Tsui and that the ozone chemistry is linear, then $81 \%(0.58 / 0.72)$ of the ozone increase at $\mathrm{CW}$ is due to the ozone increase in the background air. However, regional scale chemical transport modeling is required to validate this result. The increasing ozone concentrations at Hok Tsui, which is upwind of Hong Kong and the PRD for a majority of time, suggests the importance of taking long-range (super-regional) transport into account in the management strategy of ground-level ozone pollution in Hong Kong and the PRD. Short-term control strategies, however, should aim to reduce sources within the region, which have led to peak concentrations of 150-200 ppbv during episode days.

\section{Conclusions}

Motivated by the need to understand the atmospheric impact of East Asia's rapid industrialization, a regional air monitoring station was established in the early 1990s in a coastal area of Hong Kong. This paper presents the ozone and CO results obtained from 1994 to 2007. The 14-year data reveal increasing ozone levels at an average rate of $0.58 \mathrm{ppbv} / \mathrm{yr}$. This increase is associated with the increase in tropospheric $\mathrm{NO}_{2}$ in China's fast-developing coastal regions. These findings, combined with the back trajectory results, suggest that the observed increase in ozone levels is very likely the result of the increase in the emission of ozone precursors in upwind source regions in the eastern coastal regions of China. Long-range transport makes a significant contribution to the increase in "total ozone" in the urban area of Hong Kong, thus suggesting the importance of considering super regional transport in future ozone control strategies. Although this study indicates an association between the increase in ozone level and the increase in emissions in upwind source regions, further studies are needed to confirm this association and to quantify the relative contribution from each 
source region (including ship emissions over the oceans) to the ozone changes.

Acknowledgements. We thank J. Kwok for processing the ozone and CO data at Hok Tsui. We are grateful to the Hong Kong Environmental Protection Department for the provision of air quality data from the Central/Western Station, the Hong Kong Observatory for providing the wind data collected at Waglan Island, the GOME and SCIAMACHY science team for making available the $\mathrm{NO}_{2}$ column data. We thank $\mathrm{C}$. $\mathrm{K}$. Poon for his personal initiative, as the then President of the University, in founding the Hok Tsui station, and J. M. Ko and Y. L. Xu, also of HKPU, for their strong support of the long-term measurement program at Hok Tsui. The long-term monitoring work at Hok Tsui has been supported by the Background Air Monitoring Project of The Hong Kong Polytechnic University (S-023), and data analysis was funded by Hong Kong Polytechnic University's Niche Area Development Scheme (1-BB94). We thank co-editor, Owen Cooper, and the two anonymous reviewers for their comments and suggestions which have helped improve the original manuscript.

Edited by: O. Cooper

\section{References}

Chameides, W. L., Li, X. S., Tang, X. Y., Zhou, X. J., Luo, C., Kiang, C. S., St John, J., Saylor, R. D., Liu, S. C., Lam, K. S., Wang, T., and Giorgi, F.: Is ozone pollution affecting crop yields in China?, Geophys. Res. Lett., 26, 867-870, 1999.

Chan, C. Y., Chan, L. Y., and Harris, J. M.: Urban and background ozone trend in 1984-1999 at subtropical Hong Kong, South China, Ozone-Sci. Eng., 25, 513-522, 2004.

Cheung, V. T. F. and Wang, T.: Observational study of ozone pollution at a rural site in the Yangtze Delta of China, Atmos. Environ., 35, 4947-4958, 2001.

Chou, C. C. K., Liu, S. C., Lin, C. Y., Shiu, C. J., and Chang, K. H.: The trend of surface ozone in Taipei, Taiwan, and its causes: Implications for ozone control strategies, Atmos. Environ., 40, 3898-3908, 2006.

Cohen, D. D., Garton, D., Stelcer, E., Hawas, O., Wang, T., Poon, S., Kim, J., Choi, B. C., Oh, S. N., Shin, H. J., Ko, M. Y., and Uematsu, M.: Multielemental analysis and characterization of fine aerosols at several key ACE-Asia sites, J. Geophys. Res.Atmos., 109, D19S12, doi:10.1029/2003JD003569, 2004.

Crutzen, P.: Discussion of chemistry of some minor constituents in stratosphere and troposphere, Pure Appl. Geophys., 106, 13851399, 1973.

Dalsøren, S. B., Eide, M. S., Endresen, Ø., Mjelde, A., Gravir, G., and Isaksen, I. S. A.: Update on emissions and environmental impacts from the international fleet of ships: the contribution from major ship types and ports, Atmos. Chem. Phys., 9, 2171-2194, 2009, http://www.atmos-chem-phys.net/9/2171/2009/.

Danielsen, E.: Stratospheric-tropospheric exchange based on radioactivity ozone and potential vorticity, J. Atmos. Sci., 25, 502$518,1968$.

Ding, A. J., Wang, T., Thouret, V., Cammas, J. P., and Nédélec, P.: Tropospheric ozone climatology over Beijing: analysis of aircraft data from the MOZAIC program, Atmos. Chem. Phys., 8, 1-13, 2008, http://www.atmos-chem-phys.net/8/1/2008/.
Dorling, S. R., Davies, T. D., and Pierce, C. E.: Cluster-analysis a technique for estimating the synoptic meteorological controls on air and precipitation chemistry - method and applications, Atmos. Environ., 26, 2575-2581, 1992.

Draxler, R. R. and Hess, G. D.: An overview of the HYSPLIT_4 modelling system for trajectories, despersion, and deposition, Austral. Meterol. Mag., 47, 295-308, 1998.

Eyring, V., H. W. Köhler, J. van Aardenne, and A. Lauer, Emissions from international shipping: 1. The last 50 years, J. Geophys. Res., 110, D17305, doi:10.1029/2004JD005619, 2005.

Fiore, A. M., Jacob, D. J., Logan, J. A., and Yin, J. H.: Long-term trends in ground level ozone over the contiguous United States, 1980-1995, J. Geophys. Res.-Atmos., 103, 1471-1480, 1998.

Gao, J., Wang, T., Ding, A. J., and Liu, C. B.: Observational study of ozone and carbon monoxide at the summit of mount Tai (1534 m a.s.1.) in central-eastern China, Atmos. Environ., 39, 4779-4791, 2005.

IPCC: Climate change 2007 - Synthesis Report, 2007.

Jaffe, D., Price, H., Parrish, D. D., Goldstein, A., and Harris, J.: Increasing background ozone during spring on the west coast of North America, Geophys. Res. Lett., 30, 1613, doi:10.1029/2003GL017024, 2003.

Jaffe, D. and Ray, J.: Increase in surface ozone at rural sites in the western US, Atmos. Environ., 41, 5452-5463, 2007.

Kurokawa., J., Ohara, T., Uno., I., Hayassaki, M., and Tanimoto., H.: Influence of meteorological variability on interannual variations of the springtime boundary layer ozone over Japan during 1981-2005, Atmos. Chem. Phys., Discus., 2009.

Lam, K. S., Wang, T. J., Chan, L. Y., Wang, T., and Harris, J.: Flow patterns influencing the seasonal behavior of surface ozone and carbon monoxide at a coastal site near Hong Kong, Atmos. Environ., 35, 3121-3135, 2001.

Motulsky, H., Intuitive Biostatistics, Oxford University Press, New York, USA, 91-126, 1995.

Naja, M. and Akimoto, H.: Contribution of regional pollution and long-range transport to the Asia-Pacific region: Analysis of longterm ozonesonde data over Japan, J. Geophys. Res.-Atmos., 109, D21306, doi:10.1029/2004JD004687, 2004.

Novelli, P. C., Masarie, K. A., Lang, P. M., Hall, B. D., Myers, R. C., and Elkins, J.W.: Reanalysis of tropospheric CO trends: Effects of the 1997-1998 wildfires, J. Geophys. Res.-Atmos., 108(D15), 4464, doi:10.1029/2002JD003031, 2003.

Novelli, P. C.: Observational evidence for long-term trends in carbon monoxide, American Geophysical Union, Fall Meeting, Abstract\#A11C-0600, 2007.

NRC, Committee on Tropospheric Ozone: Rethinking the Ozone Problem in Urban and Regional Air Pollution, 19-40, 1991.

Oltmans, S. J., Lefohn, A. S., Harris, J. M., Galbal ly, I., Scheel, H. E., Bodeker, G., Brunke, E.,Claude, H., Tarasick, D., Johnson, B. J., Simmonds, P., Shadwick, D., Anlauf, K., Hayden, K., Schmidlin, F., Fujimoto, T., Akagi, K., Meyer, C., Nichol, S., Davies, J., Redondas, A., and Cuevas, E.: Long-term changes in tropospheric ozone, Atmos. Environ., 40, 3156-3173, 2006.

Oltmans, S. J., Lefohn, A. S., Harris, J. M., and Shadwick, D. S.: Background ozone levels of air entering the west coast of the U.S. and assessment of longer-term changes, Atmos. Environ., 42, 6020-6038, 2008.

Parrish, D. D., Dunlea, E. J., Atlas, E. L., Schauffler, S., Donnelly, S., Stroud, V., Goldstein, A. H., Millet, D. B., McKay, 
M., Jaffe, D. A., Price, H. U., Hess, P. G., Flocke, F., and Roberts, J. M.: Changes in the photochemical environment of the temperate North Pacific troposphere in response to increased Asian emissions, J. Geophys. Res.-Atmos., 109, D23S18, doi:10.1029/2004JD004978, 2004.

Parrish, D. D., Millet, D. B., and Goldstein, A. H.: Increasing ozone in marine boundary layer inflow at the west coasts of North America and Europe, Atmos. Chem. Phys., 9, 1303-1323, 2009.

Richter, A., Burrows, J. P., Nuss, H., Granier, C., and Niemeier, U.: Increase in tropospheric nitrogen dioxide over China observed from space, Nature, 437, 129-132, 2005.

Schnadt Poberaj, C., Staehelin, J., Brunner, D., Thouret, V., de Backer, H., and Stübi, R.: Long-term changes in UT/LS ozone between the late 1970s and the 1990s deduced from the GASP and MOZAIC aircraft programs and from ozonesondes, Atmos. Chem. Phys., 9, 5343-5369, 2009.

Shao, M., Tang, X. Y., Zhang, Y. H., and Li, W. J.: City clusters in China: air and surface water pollution, Front. Ecol. Environ., 4, 353-361, 2006.

Tanimoto, H., Mukai, H., Sawa, Y., Matsueda, H., Yonemura, S., Wang, T., Poon, S., Wong, A., Lee, G., Jung, J. Y., Kim, K. R., Lee, M. H., Lin, N. H., Wang, J. L., Ou-Yang, C. F., Wu, C. F., Akimoto, H., Pochanart, P., Tsuboi, K., Doi, H., Zellwegern, C., and Klausenn, J.: Direct assessment of international consistency of standards for ground-level ozone: strategy and implementation toward metrological traceability network in Asia, J. Environ. Monitor., 9, 1183-1193, 2007.

Tanimoto, H.: Increase in springtime tropospheic ozone at a mountainous site in Japan for the period 1998-2006, Atmos. Environ., 43, 1358-1363, 2009.

Taylor, J. K. and Cihon, C.: Statistical Techniques for data analysis, 2nd edn, Chapman and Hall/CRC, 47-71, 2004.

USEPA: EPA's Report on the Environment 2008, EPA/600/R07/045F, Washington, DC 20460, 2008.

Vingarzan, R.: A review of surface ozone background levels and trends, Atmos. Environ., 38, 3431-3442, 2004.

Wang, T., Lam, K. S., Chan, L. Y., Lee, A. S. Y., and Carroll, M. A.: Trace gas measurements in coastal Hong Kong during the PEMWest B, J. Geophys. Res.-Atmos., 102, 28575-28588, 1997.

Wang, T., Lam, K. S., Lee, A. S. Y., Pang, S. W., and Tsui, W. S.: Meteorological and chemical characteristics of the photochemical ozone episodes observed at Cape D'Aguilar in Hong Kong, J. Appl. Meteorol., 37, 1167-1178, 1998.
Wang, T., Cheung, V. T. F., Anson, M., and Li, Y. S.: Ozone and related gaseous pollutants in the boundary layer of Eastern China: Overview of the recent measurements at a rural site, Geophys. Res. Lett., 28, 2373-2376, 2001.

Wang, T., Ding, A. J., Blake, D. R., Zahorowski, W., Poon, C. N., and Li, Y. S.: Chemical characterization of the boundary layer outflow of air pollution to Hong Kong during February-April 2001, J. Geophys. Res.-Atmos., 108, 8787, doi:10.1029/2002JD003272, 2003.

Wang, T., Guo, H., Blake, D. R., Kwok, Y. H., Simpson, I. J., and Li, Y. S.: Measurements of trace gases in the inflow of South China Sea background air and outflow of regional pollution at Tai O, Southern China, J. Atmos. Chem., 52, 295-317, 2005.

Wang, T., Ding, A. J., Gao, J., and Wu, W. S.: Strong ozone production in urban plumes from Beijing, China, Geophys. Res. Lett., 33, 1-5, 2006a.

Wang, Z. F., Li, J., Wang, X. Q., Pochanart, P., and Akimoto, H.: Modeling of regional high ozone episode observed at two mountain sites (Mt. Tai and Huang) in East China, J. Atmos. Chem., 55, 253-272, 2006b.

Xu, X., Lin, W., Wang, T., Yan, P., Tang, J., Meng, Z., and Wang, Y.: Long-term trend of surface ozone at a regional background station in Eastern China 1991-2006: enhanced variability, Atmos. Chem. Phys., 8, 2595-2607, 2008, http://www.atmos-chem-phys.net/8/2595/2008/.

Zhang, J., Wang, T., Chameides, W. L., Cardelino, C., Kwok, J., Blake, D. R., Ding, A., and So, K. L.: Ozone production and hydrocarbon reactivity in Hong Kong, Southern China, Atmos. Chem. Phys., 7, 557-573, 2007, http://www.atmos-chem-phys.net/7/557/2007/.

Zhang, Y. H., Su, H., Zhong, L. J., Cheng, Y. F., Zeng, L. M., Wang, X. S., Xiang, Y. R., Wang, J. L., Gao, D. F., Shao, M., Fan, S. J., and Liu, S. C.: Regional ozone pollution and observation-based approach for analyzing ozone-precursor relationship during the PRIDE PRD2004 campaign, Atmos. Environ., 42, 6203-6218, 2008.

Zhang, Q., Streets, D. G., Carmichael, G. R., He, K., Huo, H., Kannari, A., Klimont, Z., Park, I., Reddy, S., Fu, J. S., Chen, D., Duan, L., Lei, Y., Wang, L., and Yao, Z.: Asian emissions in 2006 for the NASA INTEX-B mission, Atmos. Chem. Phys., 9, 51315153, 2009, http://www.atmos-chem-phys.net/9/5131/2009/. 